\title{
Yorùbá Coastal Christian Communities: From the Evangelist Band Mission to the Zion and Holy Apostles Communities
}

\author{
Adégbọlá Tolú Adéfi \\ Ọbáfẹmi Awólọ́wọ̀ University llé-Ifẹ̀, Nigeria \\ tolujudes@gmail.com
}

\begin{abstract}
This article highlights the diversity of African Christianity in the İlàjẹ and İkálè areas of present-day Ondo State, as well as in neighboring communities. It compares the successive religious movements led by E. M. Líjàdú and his Evangelist Band Mission, which represents an African missionary effort of the first generation in the İkálẹ and İlàjẹ areas, and the more recent Zion and Holy Apostles communities that have been established along the coast as independent Christian settlements under local spiritual leaders and kings. The article shows that there are certain similarities and differences between the successive movements. While the different conditions of the periods in which these movements operated, and the different conditions in which these religious activities were organized, matter, both movements offered their converts a new understanding of the world in which existing practices, were re-examined through an engagement with education and 'modernity' in a more general sense, and through existing forms of spiritual expression such as music, dance, and dress.
\end{abstract}

\section{Introduction}

This article traces the history of the Christian experiences and expressions of the İlàjẹ, İkálè and Ondo groups of the Yorùbá from earliest times till the present moment. Like most African societies, the İlàjẹ, İkálẹ and Ondo communities naturally followed the African religions within which the lives of 
their forebears took meaning and direction. Although Portuguese Catholic missionaries had attempted to plant Christianity in Benin City and Warri, ${ }^{1}$ they did not pursue successful missionary activities in the Îlàjẹ and İkálẹ environs. As a result, most people in these communities believed in the traditional worship passed down their lineages until Christianity was introduced in the late nineteenth and especially the twentieth century.

Historical records obtained from the archives of the Anglican Communion, Diocese of the Coast, İlútitun, Ondo State corroborate Àyándélés assertion that Christian missionary work in the eastern part of the Yoruba country began in 1875. On February 22, 1875, Rev. David Hinderer led two other Christian teachers, Messrs. C. N. Young and Hunsu Wright, to İtẹ̀bú-Mánuwá. The team left for Arijan on March 2, 1875. Crossing Ofara River, the team further made for the hinterland on March 3. The journey to Òde Ondo thereafter commenced in earnest. By March 19, 1875, they arrived at Ondo for an evangelization campaign.

After the first expedition, Rev. Charles Phillips and Mr. N. Ògbónnaiyé were sent on a second missionary journey arriving at İtẹbú-Mánuwá on January 10, 1877. Rev. Phillips was to be stationed at Òde-Ondo with the mandate to supervise the İtẹbú-Mánuwá church from his Ondo base. In spite of the various degrees of success in the evangelization of the region, the missionaries kept exploring avenues for the spread of the Christian faith among the İlàje, İkálẹ̀, Ondo and İjẹsà settlers in the region. Upon the penetration of Christianity into the eastern region of Yorùbáland, some local Christian leaders with their charisma, passion and style of evangelism transformed their areas of influence, deepening the faith in these areas in forms which are quite unique and fascinating. This work reviews the exploits of two such men: E. M. Lijàdú and Elisha Ilene Ògúnfèyímí. It also explores the circumstances leading to the founding of Ugbóńlá, a faith community of the C \& S Zion Church, and Ayetoro, the community of the Holy Apostles.

\section{Reverend E. M. Líjàdú and the Evangelist Band Mission}

Reverend Emmanuel Moses Líjàdúbí (Líjàdú) was born in Òsíẹẹ̀ town, Abéòkúta in $1860^{3}$. His father, Moses Líjàdúbí (1818-1911) was a licensed

1. J. Kenny, The Catholic Church in Tropical Africa 1445-1850 (İbàdàn: İbàdàn University Press \& Dominican Publications, 1983), 45-60.

2. M. O. Ọwàdayọ̀, "Líjàdú Movement, A Search for Status or a Product of Ethiopianism," A Paper Presented at the $6^{\text {th }}$ Annual Conference of the Nigerian Association for the Study of Religions held at the University of Jos, September 1-6, 1980, Conference Proceedings, 95.

3. Interview conducted with Dúrójayé Líjàdú on Sunday, October 30, 2016 at the İjọ İhìnrere Lọ́fẽ Headquarters, İsokùn Street, behind Saint Stephen’s Cathedral, Ondo town. 
preacher in Aké, Abéòkúta. While E. M. Líjàdú was in elementary school, a group of white missionaries visited his school. They made enquiries among pupils who wanted to venture into missionary work in the future. E. M. Lijàdú and six other pupils indicated their interest in becoming missionaries. Subsequently, they were introduced to special training classes in addition to the demands of their regular curriculum. ${ }^{4}$ On the completion of his training in the school, Lijàdú proceeded to the Teacher's Training Institute, Aké, Abéòúta, where he qualified as a class II teacher in $1888 .{ }^{5}$ Upon the acquisition of this certificate, he was adequately equipped to be employed as teacher and catechist under the CMS. Mr. Líjàdú had met Rev. Phillips in Abéòkúta while the former was a lay delegate to church meetings. ${ }^{6}$

Líjàdú had begun to show his concern for compassionate shepherding when he, together with other parishioners, petitioned the higher authority against a discriminatory policy of Rev. James Johnson, superintendent and vicar of Abéòkúta church: Johnson had excommunicated many members from the Lord's supper at Abéòúta for not having $7 \frac{1}{2}$ strings of cowries per week as a class fee. Later, Líjàdú decided to pursue a career as a missionary under the CMS at Òde-Ondo. He arrived at Ondo between October 18 and 20, 1890 as a catechist at Saint Stephen's Anglican Church where he worked directly under Rev. (later Bishop) Charles Phillips. He was appointed Deacon in 1894 and was ordained Reverend in 1896.

Soon, a combination of several factors helped Lijàdús rise to fame in the surrounding communities. They included Lijàdús proactive steps towards combating the Ondo influenza and smallpox outbreak of 1895-1896, his spiritual pedigree, his self-sacrifice, his investment of time in prolonged prayers, his rigorous spiritual discipline and fasting, and his evangelism in the interior settlements where the CMS failed to reach. Líjàdús strong zeal, missionary and evangelistic endeavors and agitations for better conditions of service were a prelude to his establishment in 1898 of the 'Prayer Band' which was in turn a spring-board for the founding of his model church. ${ }^{8}$

Dúrójayé is the great grandson of E.M. Líjàdú and the direct surviving curator of the Líjàdú Movement.

4. Interview conducted with Dúrójayé Líjàdú on Sunday, October 30, 2016 at the İjo İhìnrere Lộfě Headquarters, İsokùn Street, behind Saint Stephen's Cathedral, Ondo town.

5. Owàdayọ̀, "Líjàdú Movement," 95.

6. Ibid.

7. For the first date, see Owàdayọ̀, "Líjàdú Movement," 95. The second date emerges from an Interview conducted with Dúrójayé Líjàdú on Sunday, October 30, 2016.

8. Ọwàdayọ̀, "Líjàdú Movement," 95. 
However, some of Lijàdú's activities were simply unorthodox to the mother church. These included his interest in self-sufficiency, ${ }^{9}$ and his engagement in trading activities. Líjàdú was also a strong proponent for higher remuneration of CMS workers in 1899. Their letter of consideration for the addition of a few more shillings to their wages was addressed both to Bishop Charles Phillips and Rev. Tom Harding, Secretary to the Executive Committee in İbàdàn. The tone of Harding's reply was sharp and inconsiderate. He rebuffed the workers for their overdependence on the donations of Britons who were poorer than the receiving churches in the British colony. Although the executive committee later tried to play down Harding's letter, the conflict encouraged Líjàdú to think about how to set up a form of African Christianity that would be self-sustaining. He eventually concluded plans to form a church that was fully African and not tied to the apron-strings of the CMS.

In 1901, Líjàdú formed the Evangelist Band Mission, or İjọ İhìnrere Lọ́fĕ, which was independent of the CMS. One difference between the Evangelist Band Mission and the Anglican Church was that Lijàdú believed that an African man could have more than one wife and be given full membership of the church. He was convinced that it is not in the spirit of Christ's love to compel a man to abandon other wives apart from his first. Thus, although polygamists were denied titles and the sacrament in the CMS, the Evangelist Band Mission accorded them equal rights with other parishioners including full membership.

Lijàdú also found a way of linking the local Ifá divination and Christianity. During his employment by the CMS, Lijàdú had been commissioned to conduct a thorough investigation of the Ifá divination system to educate members of the CMS. Líjàdú believed in the lordship of Jesus Christ and acknowledged him as the son of God, but he argued that the Ifá divination system was an embodiment of the Yorùbá tradition that stood in a class of its own. According to J.D.Y. Peel, Líjàdú argued that through Ifá and its deity Òrúnmílà, the Yorùbá received a partial pre-revelation of Jesus Christ. Lijàdú gave the name Òrúnmílà the interpretation "it is heaven that knows reconciliation", pointing to Jesus as its fulfillment. ${ }^{10}$ The Christian theology of Ifá which Líjàdú proposed presents Ifá as a partial revelation of God which serves as praeparatio evangelica (preparation towards evangelism) among the Yorùbá - the type that Paul identified and upon which he built his evangelical discourse with the people of Athens (Acts 17: 22-26). With this unique perspective, Lijàdú contrib-

9. Ibid.

10. J.D.Y. Peel, Christianity, Islam and Òrìà Religion: Three Traditions in Comparison and Interaction (Oakland, University of California Press, 2015), 154. 


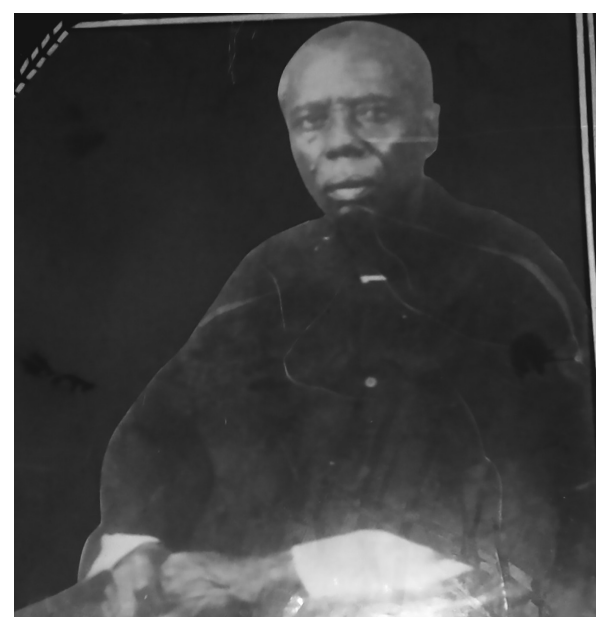

Figure 1. Reverend E. M. Líjàdú. Source: Family archives, Líjàdú family, with permission.

uted both to the building of Yorùbá cultural nationalism and the emergence of a distinctive Yorùbá Christianity. ${ }^{11}$

According to Dúrójayé Líjàdú, Líjàdú’s great-grandson, Líjàdú’s work on Ifá also enabled him to develop a distinct form of African Christianity that was both unique and dissimilar from European understandings of Christianity because he made some discoveries during his study which were to be useful to him later as the leader of the Evangelist Band Mission.

Spreading Christianity through music and with respect for polygamists and Ifá divination, Líjàdú's Evangelist Band Mission was instrumental to the establishment of Christian congregations in towns including Igbótako, Igbóègùnrin, İtẹbú-Kúnmí, Igbólómi, İkọ̀yà and Òkìtìpupa in the years before 1903. He continued to propagate the Christian message in the villages of the old İkálè kingdom of Ộọ̣ọ̣ọ̀, such as İgò-Àdùwọ̀, Agírífon, Òkèrìsà and Irá.

In recognition of Líjàdú's activities in the coastal region, CMS Bishops Tugwell and Olúwolé visited the fast growing mission field in 1906. The bishops were astonished at the activities of the Band and made efforts to boost Líjàdú's work in the area by sending Mr. B. I. Mánuwá, a Deacon, to Ayésan from where he supervised the work at İtẹbú, Èkímọ̀nà and Òkélówó. ${ }^{12}$ Líjàdú also worked closely with CMS missionaries like Tàkúnó Ọjágbóhúnmi and Mis-

11. Ibid.

12. Manuscript on the history of Saint John's Anglican Church, Igbótako, obtained on October 20, 2016 at the Diocese on the Coast, Anglican Communion (first draft). 
tress Dorcas Abiọ́dún Ògúnrò, ${ }^{13}$ who pioneered CMS work in communities like Igbótako.

For most of his life, Líjàdús relationship with the CMS was fluid: the İjo İhìnrere Lọ́fẽ has a documented set of ordinances, liturgies, songs and doctrines which are close to those of the CMS, even though it retains its acceptance of polygyny and appreciation of Ifá. For that reason, many of the churches Líjàdú helped found while he was a CMS agent comfortably remained under his control after he severed ties with the CMS.

One of the reasons for the clear break between the CMS and the İjọ İhìnrere Lọ́fě was that Folárìn Líjàdú, who, like his father had trained to be a priest under the CMS, was refused consecration and ordination unless his father formally agreed to bring churches founded by him while working for the CMS back under CMS control. This demand did not go down well with his father, who then decided to ordain Folárìn as priest under the İjọ İhìnrere Lọ́fẽ movement.

Upon the demise of E. M. Lijàdú, his son, Folárìn Líjàdú, took over the movement. But some followers of Líjàdú were not pleased with the emergence of his son and decided to turn over the local churches and their congregations to the CMS. These actions depleted the strength and reach of the İjo İhìnrere Lọ́fĕ. The church was later passed on to his grandson Ezekiel Lijàdú (19322014). Unfortunately, his great-grandson who was being groomed for the position died shortly before Ezekiel in 2014. Dúrójayé, the next in line in the lineage revealed an uncommon ordination type to be conducted by Ezekiel, his late father, which would take place in the realm of the spirit. However, only five churches remain under the control of the Líjàdú movement today. ${ }^{14}$

Like the Anglican Church in the West, ${ }^{15}$ the İjo İhìnrere Lộfẽ also ordains women to the priesthood. In fact, on the day the church was visited, there were two officiating ministers, a male and a female. Aside from the sermon delivered by the male priest and the coordination of the tithes and offertory gifts, other aspects of the devotion were either led by the female priest or by other female members of the congregation. Unique priestly regalia, which were the signature tune of late Folárìn Líjàdú and Ezekiel Lijàdú, were emblematic of a blend of Western type and African type ministerial outfits (see fig. 2).

In addition to wearing the European style of priestly attire, both also appeared in an overflowing cloak or gown locally known as agbádá for the performance of their official duties. This signifies their acceptance of both the

13. Ibid.

14. Apart from the headquarters that was visited, there is a branch in Òitipupa while three branches are located in Ògùn State.

15. This practice is not popular among Anglicans in Nigeria. 


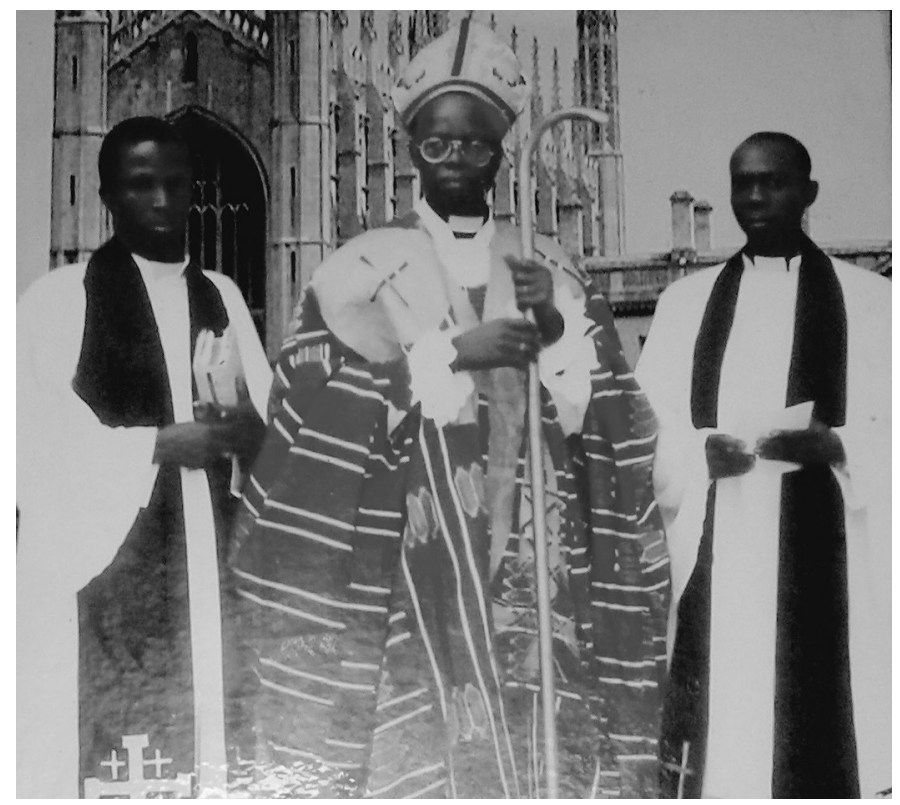

Figure 2. Archbishop Ezekiel Líjàdú and two of his priests. Source: Family archives, Líjàdú family, with permission.

Christian and Yoruba traditional religious views. From the days of Folárìn to the present moment, each son and heir of the Lijàdú movement has a mandate to offer an annual sacrifice in honor of his departed father. This practice is more reflective of the Yorùbá worldview than the Western Christian type.

When prayers are being offered, it is expected that those hearing the blessings say words that would activate the declarations or wishes. To such prayers, it is customary in most churches to say 'Amen', meaning 'so be it' in Latin. The İjọ İhìnrere Lọ́fĕ adopted the Yoruba equivalent of amen by using local word "Áásẹ", which is chanted during offertory prayers and declarations.

It is evident that the İjọ İhìnrere Lọfĕ has waned in followership and membership since the days of Líjàdú. One may therefore be tempted to conclude that the movement is not vibrant. However, affiliation with African Islam, African Christianity and African autochthonous religious traditions is on the increase. Lijàdú may not command a large physical followership in his church today but Africans and peoples of other continents whose love and admiration for shades and forms of such movements which Líjàdú represents are increasing daily. In fact, there seems to be a revival and a rejuvenation of interest in many things African and traditional around the world.

One may therefore need to be humble and introspective in forming opinions and views as to whether Líjàdú's toils and struggles in founding a religious 
movement completely indigenous and free of external funding or control continues to achieve its aims. As Lijàdú pioneered the indigenous missionary movements even before the emergence of the religious revival leading to the establishment of the Aládŭrà churches, he certainly pioneered many practices. Pentecostal charismatic figures in the religious landscape of the country today started movements and ministries which are growing and spreading their frontiers to those nations from where Christianity was exported to Nigeria. As pioneered by Lijàdú, each of them has at least one signature tune which has become their trademark.

\section{The Rise of Aládŭrà (Praying) Churches and the Foundation of Ayétòrò and Ugbóńlá}

Like the İjọ İhìnrere Lớfě, the Cherubim and Seraphim Society was not originally set up as a new church or break-away movement. Born into the royal family of İkàrẹ (Ả kókó) in 1879, Moses Orímọládé Túnọláse was brought up as an Anglican and later worked as an itinerant preacher. Like others at the time, Orímọládé emphasised the importance and power of prayer, or Àdúrà, and in many of the cities he traversed both in southern and northern Nigeria, ministering to willing individuals and groups between 1916 and 1924, Aládŭrà (praying) groups or churches formed in response to his preaching. ${ }^{16}$ In 1925, Orímọládé and his newly formed Aládŭrà Band visited Lagos when he was asked by Mrs. Comfort Hunnu-Moiett to come to her home for a special prayer for her and her husband's ward, Christiana Abiọ́dún Akínsọ́wón. Akínsọ́wón, born in Abéòkúta, had by then been unconscious and in a trance for several days after having glimpsed the chalice carried at a Catholic mass. She later reported that she was at that time undergoing heavenly training preparing her for celestial duties.

Abiọ́dún was brought back to full consciousness after Orímọládé had prayed and sang praise to God on her behalf. Upon her return to full consciousness after the episode of the trance, the crowd that daily thronged the home of the Moietts was embarrassingly large. In order to maintain their privacy, they asked Orímọládé to take Abióndún to his own residence in Àgọ́-Î̀sòfin. At Orímọládés residence, inquisitive visitors came around and often joined prayer meetings with Orímọládé and Abíọ́dún as leaders. From the regular prayer meetings arising from the inquisition visits over Abiọ́dún’s experience, the Cherubim \& Seraphim Band was formed, which was led by both Orímọládé and Abiộdún. However, in 1929, Orímọládé and Abiọ́dún separat-

16. J. A. Omọ́yájowó, “Moses Orímọládé Túnọláse: 1879-1933," Makers of the Church in Nigeria (Lagos, CSS Bookshops Limited, 1995), 124. 
ed, and formed different groups, all of which referred to the Cherubim and Seraphim (often abbreviated as C\&S) by name. Their trademarks were preaching faith in prayers and a renunciation of the devil and his works, such as idol worship, the use of juju (magic), charms and witchcraft.

As Orímọládé, Abióndún, and other disciples founded branches of the Cherubim and Seraphim in many locations within and outside Lagos, one of Orímọládés followers, Timothy Orògbèmí from the İlàjẹ area, was sent to establish the C \& S church in his home community. ${ }^{17}$ By 1929 , the first C\&S church was established in the Îlàjẹ area by Orògbèmí. Many İlàje indigenes embraced the faith and helped to spread it all over the area. Some of the prominent people who embraced the faith, further assisting the C\&S movement in İlàjẹland and beyond include St. Ėréjuwà Máfọ́, founder, Episcopal C\&S Zion Church, Zion-Pẹ̀pẹ̀, St. Joshua Șemúdàra, founder, Truthful Angelic C\&S Zion Church, Zion-Màhin, St. Albert Ukawa aka Kelema, founder, Holy Messiah C\&S Zion Church, Aroun, Delta State, St. Olọ́runlànà, founder, C\&S Zion Church, Zion-Sèjá-Odò, St. William Ọmọ́tèrè Ayèọmọ Enilàńjẹ, founder, C\&S Zion Church, Zion-Àkàtà and St. Elisha Ilene Ògúnfèyímí, founder, C\&S Zion Church, Zion-Ugbóńlá (see fig. 3).

Without denying the importance of Orògbèmís contribution to the growth of $\mathrm{C} \& \mathrm{~S}$ churches in the İlàjẹ area, Elisha Ilene Ògúnfèyímí was also reputed to have personally received the mandate to return to the İlàje area from Lagos where he had been commissioned by Orímọládé to establish the C\&S in his birthplace, the Ügbò kingdom. ${ }^{18}$. Elisha Ilene Ògúnfèyímí was born in Eruna in the Ügbò Kingdom of İlàjẹ Local Government Area, Ondo State to late Pa Jacob Ògúnfèyímí Ọdọlá and late Madam Ọlayẹníká Ògúnfèyímí in 1901. ${ }^{19}$ The local deity of Ogunfeyimi’s family as his name suggests is 'Ògún', the patron saint of smithery and iron. Before Ògúnfèyímí turned eight, he had started seeing visions. He would be able to predict the imminent attack of a person by a wicked individual and the mode of such attacks accurately. He would also foretell the death of some other folk but offer a way out. The victim would only be spared if the antidotes were adhered to. Such were signs of a promising prophetic career for Ògúnfèyímí in the years to come. ${ }^{20}$

17. Interview with Primate (Dr.) S. O. Ayéọmọ, Founder, C \& S Zion, Àgbàlá Ireayọ̀mídé, Odò İkòyí, Àkúrẹ on October 27, 2016. The interview was held at his Church premises.

18. Interview with Snr. Boanergie C. O. Omọ́gbèmí, Principal School of Theology, Ugbóńlá Headquarters and Secretary General of the C \& S Zion Church, Ugbóńlá on October 19, 2016. Interview held at the health center, Ugbónlá.

19. S.O. Jedo, "Ògúnfèyímí Elisha Ilene (1901-1996): Cherubim and Seraphim Church of Zion, Nigeria," http://www.dacb.org/stories/nigeria/ogunfeyimi_elisha .html, accessed October 6, 2016.

20. Interview with Snr. Boanergie C. O. Omọ́gbèmí, October 19, 2016. 


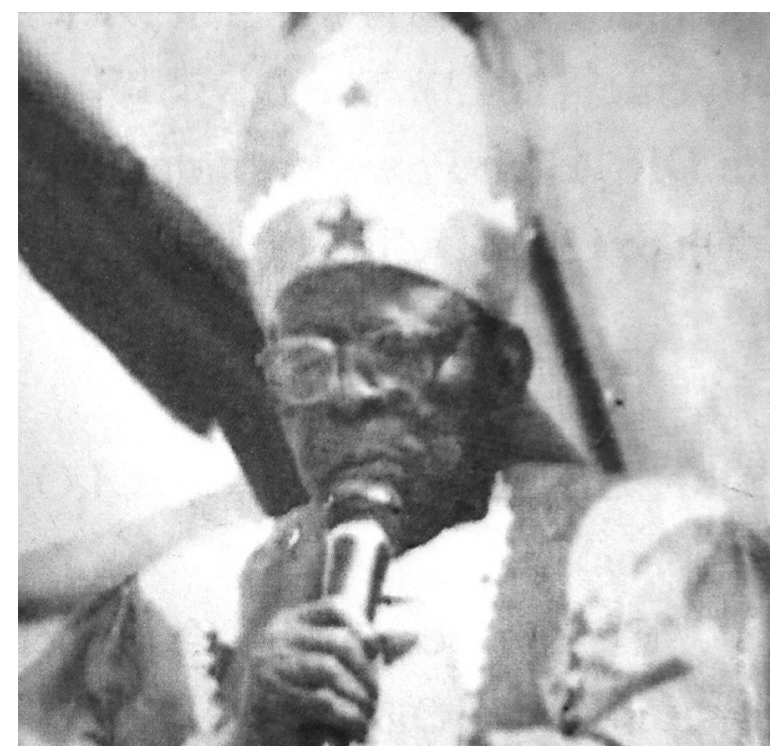

Figure 3. Elisha Ilene Ògúnfèyímí. Source: Primate (Dr.) S. O. Ayéọmọ, Founder, C \& S Zion Church, Àgbàlá Ireayọmmídé, Odò İkòyí, Àkúrẹ́. Photograph taken by Ọládŭnní Ọsanyìnbí on January 18, 2017 with permission.

During his early life, Ògúnfèyímí worked as a commercial boat rower commuting between Erunà, Atíjeré and Lagos. Later, he engaged in trading in foods, clothes and other goods before venturing into fishing. He started this new trade from Erunà to Lekki in Lagos and eventually to the seashore around Sumoge, Delta State. His eventual call to Christian service began when he joined the West African Episcopal Church (WAEC), Erunà, where he later became choir leader. While he was serving as choir leader in the Episcopal Church at Erunà, Bishop Campbell would often send a canoe to ferry him from Atíjeré as his absence during the choir renditions was noted. It was while he was busy building the choir that God called him. ${ }^{21}$

After receiving his calling, Ògúnfèyímí joined the C\&S in Lagos under Moses Orímọládé Túnọláse. He became powerful in vision, healing and miracles at the C\&S in Lagos having joined the church in 1925. He also received some training under Moses Orímọládé Túnọláse who predicted that Ògúnfèyímí would later become a prominent prophet of the C\&S Church. In 1933, he was ordained by Orímọládé as Senior Leader. Upon Ògúnfèyímís return to the creeks of İlàjẹ, he formed a conference from a group of churches.

21. Ibid. 
When Ògúnfèyímí turned forty seven years, he saw a scary vision where he was taken to the swampy, deadly forest of Ugbóńla near his hometown. The forest was reputed to be the home of deadly animals, ghosts and criminals. It was a place where wicked people were also buried. In Ògúnfèyímís dream, a big church emerged in this forest and he was asked to consecrate the forest to God. Believing to follow divine instructions, he moved into the forest with a group of people, including his family members, on February 16, 1948, to found the settlement of Ugbóńlá. The new settlement grew to become a theocratic community headed by Ògúnfèyímí, its pioneer king and prophet. Through divine help and his forbearance, he was able to provide leadership to build the community from scratch to become a prosperous place for all to live in. ${ }^{22}$

Ògúnfèyímí was not the first visionary to establish a Christian community in İlàjẹ: Ugbóńlá followed in the footsteps of the Ayétòrò community, which was established by the Holy Apostles, a breakaway group of the Cherubim and Seraphim Society, in 1947. Frustrated with the ongoing and common practice involving the killing of twin and albino children, and determined to abolish the worship of the traditional deities, the Late Zebulon Eyinẹ Aládétìmẹhìn had started predicting the founding of Ayétòrò and the birth of the Holy Apostle Church about two full years before the community came into being. ${ }^{23} \mathrm{E}$. O. Peter Ọjágbóhùnmi became the first political and religious leader of the community when it was founded. On January 12, 1947, a team of İlàjẹ men, women, youths and children were instructed to leave their communities to a place they would be shown. They took their nets, cages, vessels and other belongings in the twilight and travelling in their canoes, arrived in Ayétòrò on the Atlantic coastline, where they were divinely instructed to settle. ${ }^{24}$

Perhaps because Ayétòrò was the first Christian community to be established, both in İlàje and in Nigeria more generally, it attracted a lot of opposition. Several members of the new community were harassed or persecuted for their perceived effrontery against the established customs. A good number of people was arrested, prosecuted and jailed for daring to challenge the local deities and community cults. It is believed today that many of them were divinely preserved from death when they were fed with food containing concentrated poison. In memory of their exodus and persecution, the people of Ayétòrò hold the biggest

22. Ibid.

23. Interview with Rev. Pastor Andrew Aládétìmẹhìn, Minister at Orí Òkè Àlááfià Ile-Rama, İgbọ́kọ̀dá Branch, Orí Òkè - İwàmímọ́ Headquarters. Interview held on October 19, at Ìlàje Local Government Headquarters, İgbọ́kọdá. Rev. Pastor Andrew is the son of Eyinẹ Aládétìmẹhìn who prophesied the founding of Ayétòrò.

24. Interview with Irètólú Àjínde, Youth Chairman of Ayétòrò Community. Interview was conducted at Ayétòrò on October 20, 2016. Irètólú was in the company of Messrs. Ọmọjunoriolú Àjínde and Òrìsàhèyí 'Sanmí when Àjínde was interviewed. 
annual religious festival on 12 January. On such occasions, all inhabitants of Ayétòrò wear old and sometimes tattered clothes, and pick their very old vessels, fishing nets and other possessions which they brought with them from their previous communities. Acting as though just arriving at Ayétòrò, they then embark on a procession around the settlement. This is followed by a religious service in the community church and a night reception and celebration at the king's palace. Other annual festivals celebrated in the community include the Annual Day of the Liberation of Twins on 18 August, which is celebrated as because it was on this date that the colonial court confirmed the assertion by the Ayétòrò settlers that the killing of twin babies was prohibited. Another big celebration takes place on the eve of the New Year, when all inhabitants of Ayétòrò converge on the open ground and remain there till 12:00 midnight, when they will commence celebration and prayers as the New Year starts.

As Ayétòrò was formed by a group of men, women, youths and children who shared similar spiritual perspectives, they also agreed on quite a number of issues. One of the areas of their agreement was on the need for unity and brotherhood to build up the community. Thus the Ayétòrò people gave up their rights to own and control resources as individuals and decided to pull their resources together for the development of their new home. Proceeds from fishing and other commercial activities were put into a single purse deployed for community projects. The wealth created in this manner allowed the community to build an ice making factory, a soap making industry, carpentry industry, and transport boats traversing Sapele, Warri, Lagos and other communities. Through community efforts, roads and walkways were built, and by 1956, Ayétòrò began to generate electricity. The Ayétòrò settlement prospered through communism, even as it had a king. It was only when the founding fathers began to die that this aspect of their vision died with them: by the late 1980s, communism had crumbled in Ayétòrò. ${ }^{25}$

Even though Ògúnfèyímí did not adopt communism for Ugbóńlá, he also invested in the community's infrastructural and educational provision. In 1949, an elementary school was founded in Ugbóńlá. The school was run without any cost to pupils and their parents. Unlike the government schools, which cost parents money at this period, the C\&S schools were free. In 1951, government took over the control of these schools, and it was not until the mid-fifties when the government of the late sage, Obáfẹmi Awólộọ̣ introduced the free education to the then Western Region of Nigeria, that they were funded by the state. By 1957, Ugbóńlá had its first Secondary Modern School. The school metamorphosed into a Secondary School in 1976. ${ }^{26}$

25. Ibid.

26. Boarnegie Omọ́gbèmí was one of the pioneer teachers in the school after its elevation to the status of a secondary school. Mr. Iroju, an Ijaw man was the first Principal in 1976. 
Ògúnfèyímí also established a School of Theology to train ministers and leaders in the C\&S Church of Zion worldwide. ${ }^{27}$ Some of the trainees are sent from branches of the church from elsewhere while the church leaders at Ugbóńlá also identify some potentially gifted and vibrant members through divine inspiration. Those so identified are encouraged to consider working in the priesthood but the final decision lies with the individual. ${ }^{28}$ The training, which is conducted biennially, lasts for a period of six months during which the trainees are taken through courses in Church Administration, Evangelism and Financial Management among other tasks. In some cases, the church leaders assist trainees in locating their areas of calling while in others, the church that has sent the candidate also helps the trainee to make such a decision. Male graduates from the School of Theology are conferred with any of the following priestly titles; Apostle, Prophet, Evangelist, Pastor, Rabbi, Senior Cherubim etc. Female graduates are conferred with titles including Queen of Sheba, Mary, Martha and Prophetess etc.

Like Ayétòrò, Ugbóńlá set up a public electricity system by 1954 . Through the goodwill enjoyed by some notable Nigerians due to their association with Ògúnfèyímí and Ugbóńlá community, some donations were made to the community. The supply of electricity was supported by Chief Olú Akínfòsílè while a big cathedral piano was given to the community by Chief Festus Okotie-Eboh. Another notable development Ògúnfèyímí brought to Ugbóńlá was the facilitation of the establishment of a Postal Agency in the community in 1955. As a result, Ugbónlá became the link for communication between the creeks of İlàje and the entire world. Ugbóńla was one of the first beneficiaries of a dispensary in the İlàje environs in 1958. Each community applied to the government for the establishment of such facility and about two or three such facilities were built in the whole of the İlàje communities around this time.

In Ugbóńlá, Ògúnfèyímí followed the example of Ayétòrò in other ways too. Like Ayétòrò, Ugbóńlá operates as a theocracy that is ruled by a divinely chosen leader and priest, and it also regularly celebrates its establishment. Interestingly, in both communities there have been difficulties in ensuring the smooth transition of office, and often sections of the population that were unhappy with the new choice of ruler have founded their own towns or villages. As a result, a large number of offshoot theocratic villages have been established along the İlàjẹ coast.

In both Ayétòrò and Ugbóńlá, all citizens are members of the same Christian community. To keep things that way, marriage is encouraged between community members, and in Ogúnfèyímís life time, bride wealth in Ugbóńlá

27. Interview with Snr. Boanergie C. O. Omọ́gbèmí, October 19, 2016.

28. Interview with Primate (Dr.) S. O. Ayéomọ, October 27, 2016. 
was fixed at twelve Shillings. Today members are however admonished to collect a reasonable bride wealth but not 'sell' their daughters to the highest bidder. No Zion Minister is on a regulated payroll. When a minister blesses anyone, the individual is at liberty to present a gift to the minister, but it is not a matter of compulsion..$^{29}$ The churches are quite poor, and unlike in most other churches, congregants are not even required to attend church services with money if they do not have the means.

In both Zion and Holy Apostles churches, services are held twice daily (once early in the morning and once in the early evening), and Sunday services last for about four to five hours. However, it seems that services are shorter and held with greater regularity in Ugbóńlá and Zion churches, and longer but more flexible, i.e. determined by the Spirit, in Ayétòrò and Holy Apostles churches. An important difference is that the religious practices and prophetic utterances used in the Holy Apostle Church of Ayétòrò have some semblance with Islamic practices. J. D. Y. Peel observes that Muslim names given to children, burial rites, language of the Spirit, together with the turban and gowns of the prophets of the Holy Apostle of Ayétòrò are akin to those of Muslims. ${ }^{30}$ This is also true for the sounds made by those filled with the Holy Spirit and speaking in tongues, who often sound as if they were Muslims at prayer.

Objects considered sacred in the Zion and Holy Apostles Churches include water, which is often imbued with healing powers through prayer and then administered medically. Anointing oil can be used in a similar manner. Bells are of particular importance because they are used to call the attention of the congregation during meetings and for other spiritual purposes. On a visit to the İjọ İhìnrere Lớfé, the bell on the altar was used by a woman who led the church in some prayers during the service, the use of bells in Zion churches is restricted to the leader of the congregation. Zion churches can easily be identified by the flag that is hoisted next to them.

A kind of drum called bẹmbẹ is a common feature in C \& S Zion Churches. These are beaten with one hand with the aid of a stick and are also used by Sango and Ògún worshippers. However, it is believed that the inspiration produced by these drums during religious meetings also empowers Christian worship. In Zion churches, male and female members also sit facing each other across the centre of the auditorium/meeting room. But preachers rarely preach. Rather, they are said to be dancing while bringing the congregation the divine message they have been sent. This is so because they are often under the influence of the Holy Spirit.

29. Interview with Primate (Dr.) S. O. Ayéomọ, October 27, 2016.

30. Peel, Christianity, Islam and Òrì̀à Religion, 177. 
And finally, members are usually dressed in white apparels to church meetings. ${ }^{31}$ The white color symbolizes holiness and purity, and although the church allows the use of colored clothing on other days and during revival services, only the white garments are used during Sunday services. In addition, these churches have designed clerical garments meant for each priestly class. A senior priest could choose to be clad in the apparel of a junior order but juniors do not have the privilege to wear clerical garments designed in the manner of a higher priestly order.

Today, visits to İkálẹ, İlàjẹ and Àkúrẹ areas confirm that branches of the $\mathrm{C}$ \& S Zion Churches are found in their numbers in the communities. While not all churches are part of independent communities like Ayétòrò and Ugbóńlá, there seems to be a form of autonomy given to founders of C \& S Zion churches in the Diaspora. However, the Zion churches at least still refer to the Holy City of Ugbóńlá in matters of clerical training and other salient administrative matters. Today, C \& S Zion Churches are found in Gabon, Cameroon, Gambia and many other African countries. The church also has branches in the USA, the UK and some other European nations. ${ }^{32}$

\section{Conclusion}

In addition to providing salient details on the unique and dynamic ways in which African Christianity is being practiced in the eastern part of Yorùbáland, this article shows that there are certain similarities and differences between the successive movements of İjọ İhìnrere Lọ́fĕ and the Aladŭra (Praying) churches, and especially the churches of Zion and the Holy Apostles, in the Yorùbá-speaking coastal areas of İkálẹ, İlàje, and their Yorùbá and Ijaw neighbors. Both the İjọ İhìnrere Lọ́fĕ and the Aladŭra churches offer a form of Christianity that was linked to local forms of spiritual expression, especially music and dance, but also other objects such as water, oil, flags, drums, and bells, which are reputed to have local spiritual significance. They were also often linked to the introduction of complex hierarchies, which was usually reflected in impressive titles and the regulated use of cloth (dress). Both also offered their converts a new understanding of the world, albeit in very different ways.

Overall, the İjọ Ìhìnrere Lọ́fĕ made mission Christianity compatible with practices and beliefs in rural areas by accepting pre-existing polygyny and by affirming that Christianity was partly predicted by Ifá divination. In contrast, the Zion and Holy Apostles movements insisted that Christianity could trans-

31. A girdle is usually worn with the garment.

32. Interview with Snr. Boanergie C. O. Omọ́gbèmí, October 19, 2016. 
form local lives far more dramatically than the missionaries had envisaged. However, it is important not to overstate this difference. When the İjo İhìnrere Lọ́fĕ began its activities, Christianity was still very much a European practice, and despite the efforts of Lijàdú and his Evangelist Band Mission, Christians were often allocated land that was (then) somewhat outside of the settlement. And while the Aládŭrà-inspired movements were strongly critical of some local practices, such as the killing of twins, and prepared to experiment with (Christian) communism, they also drew on the model of existing towns headed by rulers to form their new settlements.

Like other Christian movements in southern Nigeria, the İjọ İhìnrere Lớfe, the Zion Churches, and the Holy Apostles communities transformed the lives of converts through the association of Christianity with education and trade, thereby linking Christianity to important aspects of the popular ambitions in the colonial and postcolonial period. All movements also emphasized the importance of self-sufficiency, even though the Aládurrà communities had better luck in attracting additional or state funding because they operated at a period of state-led development. Both also emphasized the importance of Christian reciprocity and community, even though Líjàdú limited this to the arrangements of support for different members of the Evangelist Mission Band.

Finally, it seems that all movements were exposed to threats at the moment of leadership succession, but this affected them in different ways due to their different organizations. Disagreements over succession in the İjọ İhìnrere Lọ́fẽ led to the eventual return of many village churches to the CMS, which diminished the influence of the organization. In contrast, the town-based set-up of the Zion and Holy Apostles churches enabled those unhappy over succession arrangements at different junctures to leave and found their own settlements and town quarters. The overall success of this practice is attested by the high number of Zion and Holy Apostles churches across the coastal area.

However, disputes about succession also contributed to larger tensions. It was widely believed that before the death of Ògúnfèyímí at the age of 95 in 1996, he named his deputy Jemine, originally a member of the Arogbo Ijaw group, as his successor. However, eventually the late leader's son, Apostle Dúrójayé Ògúnfèyímí, followed his father as the leader of the settlement. ${ }^{33}$ This was seen by some members of the Zion movement as suggesting that while the İlàje welcomed other believers, they wanted to maintain control over

33. It was asserted in certain quarters that Ògúnfèyímí had indicated that his position in the church was reserved for Jemine while the crown he wore belonged to his son, Dúrójayé. This statement is credited to Primate (Dr.) S. O. Ayéọmọ, Founder, C \& S Zion, Àgbàlá Ireayọ̀mídé, Odò İkòyí, Àkúrẹ́. He revealed this on Wednesday, January, 25, 2016 in his church premises. 
them. Thus, while the church of Zion was formerly a force for unity between İlàjẹ and Ijaw, unhappiness over Ògúnfèyímís succession in the Arogbo Ijaw areas may have contributed to intergroup violence in 1998-9. This suggests that succession remains one of the most important questions to be addressed by any new Christian movement. 